\title{
DINAMIKA PERANAN SEKTOR PERTANIAN DALAM PEMBANGUNAN EKONOMI DI KAWASAN SOLO RAYA
}

\author{
Wiwit Rahayu, Nuning Setyowati ${ }^{1)}$ \\ ${ }^{1)}$ Program Studi Agribisnis Fakultas Pertanian Universitas Sebelas Maret \\ email: wiwit_uns@yahoo.com
}

\begin{abstract}
This study aims to determine the dynamics of agriculture role in economic development in the region of Solo Raya seen from agricultural sector contribution to the PDRB, the agricultural sector is base sector or not based on the Location Quotien (LQ) analysis, as well as the agricultural sector classification based Klassen Typology analysis. The data used is PDRB of Regency and City in Solo Raya Region and PDRB of Central Java in 2010-2014 based on constant prices of 2010. The results showed that during the 2010-2014 agricultural sector contribution to the PDRB of Regency / City in Solo Raya Region tends to decrease. Contribution of agriculture to the PDRB is highest in Wonogiri regency is $35.01 \%$ and the lowest was in Surakarta, namely $0.52 \%$. LQ analysis results indicate that the agricultural sector is base sector in Sragen, Wonogiri, and Boyolali and in Sukoharjo, Karanganyar, Klaten and Surakarta is not base sector. Based on the analysis Typology Klassen, the agricultural sector in Sragen, Sukoharjo, Boyolali, Wonogiri, Karanganyar, and Klaten, categorized as a potential sector, while in Surakarta categorized as a growing sector.
\end{abstract}

Keywords: agricultural sector, LQ, Solo Raya, typology klassen

\section{PENDAHULUAN}

Pembangunan merupakan suatu proses multidimensional yang mencakup berbagai perubahan mendasar atas struktur sosial, sikap-sikap masyarakat dan institusi-institusi nasional, disamping tetap mengejar akselerasi pertumbuhan ekonomi, penanganan ketimpangan pendapatan, serta pengentasan kemiskinan (Todaro, 1999). Pembangunan ekonomi daerah adalah proses di mana pemerintah daerah dan masyarakatnya mengelola sumberdaya-sumberdaya yang ada dan membentuk suatu pola kemitraan antara pemerintah daerah dengan sektor swasta untuk menciptakan suatu lapangan kerja baru dan merangsang perkembangan kegiatan ekonomi (pertumbuhan ekonomi) dalam wilayah tersebut (Arsyad, 2009). Perekonomian daerah dalam suatu negara dipengaruhi oleh setiap sektor secara berbeda-beda, misalkan beberapa daerah mengalami pertumbuhan pada sektor industri sedangkan daerah lain mengalami penurunan (Kuncoro, 2004).

Sektor pertanian merupakan salah satu sektor ekonomi yang berperan penting dalam pertumbuhan ekonomi.Pertanian dapat bekerjasama secara harmonis dengan sektorsektor lain untuk menghasilkan pertumbuhan yang lebih cepat, mengurangi kemiskinan, dan melestarikan lingkungan. Dunia pertanian berkontribusi pada pembangunan sebagai sebuah aktivitas ekonomi, sebagai mata pencaharian dan sebagai cara untuk melestarikan lingkungan, sehingga menjadikan sektor ini sebuah instrumen unik bagi pembangunan (Grup Bank Dunia, 2008).

Kontribusi sektor pertanian terhadap perekonomian nasional Indonesia semakin nyata. Selama periode 2010-2014, rata-rata kontribusi sektor pertanian terhadap PDB mencapai 10,26\% dengan pertumbuhan sekitar 3,90. Pada periode yang sama, sektor pertanian menyerap angkatan kerja terbesar walaupun ada kecenderungan menurun. Pada tahun 2014 sektor pertanian menyerap sekitar 35,76 juta atau sekitar 30,2\% dari total tenaga kerja (Kementerian Pertanian, 2015).

Solo Raya adalah wilayah geografis di Jawa Tengah yang merujuk pada eksKaresidenan Surakarta yang sering disingkat dengan nama Subosukawonosraten. Solo Raya terdiri dari tujuh wilayah administrasi, mencakup satu kota dan enam kabupaten yaitu Kota Surakarta (Solo), Kabupaten Boyolali, Sukoharjo, Karanganyar, Wonogiri, Sragen, dan Klaten. Pembangunan ekonomi kawasan Solo Raya ditopang oleh beragam sektor perekonomian. Masing-masing daerah di kawasan Solo Raya memiliki potensi ekonomi yang berbeda-beda. Hasil penelitian Cahyono dan Wijaya (2014) menunjukkan bahwa sektor unggulan tiap kabupaten di wilayah penelitian 
berbeda yaitu Wonogiri (sektor pengangkutan dan komunikasi), Karanganyar (sektor industri pengolahan), Boyolali (keuangan, real estate dan jasa perusahaan), Sragen (sektor pertanian, peternakan, kehutanan dan perikanan) dan Klaten (sektor konstruksi).

Dinamika peranan sektor pertanian di kawasan Solo Raya dalam penyerapan tenaga kerja pernah diteliti oleh Darsono, Marwanti, dan Barokah (2011). Hasil penelitian menunjukkan bahwa dalam kurun waktu 20052009 dinamika peranan sektor pertanian dalam penyerapan tenaga kerja di kawasan Subosukawonosraten dilihat dari angka pengganda tenaga kerja mengalami pasang surut. Sektor pertanian memiliki nilai komponen pertumbuhan regional terbesar dibandingkan dengan sektor lainnya yang berarti sektor pertanian memiliki peran penting dalam menyerap tenaga kerja di kawasan Subosukawonosraten. Dilihat dari efek alokasi, di kawasan Subosukawonosraten sektor pertanian mengalami spesialisasi, memiliki keunggulan kompetitif untuk menciptakan lapangan kerja dan memiliki kemampuan menggerakkan lapangan kerja kepada sektor lainnya, namun masih dikalahkan sektor konstruksi.

Dinamika peranan sektor pertanian dalam pembangunan ekonomi di kawasan Solo Raya penting untuk senantiasa diperhatikan agar sektor pertanian dapat dikembangkan dan ditingkatkan peranannya sesuai dengan potensinya. Berdasarkan latar belakang tersebut penelitian ini bertujuan untuk mengetahui dinamika peranan sektor pertanian dalam pembangunan ekonomi di Kawasan Solo Raya dilihat dari kontribusi sektor pertanian terhadap PDRB, pertumbuhan PDRB sektor pertanian, basis dan tidaknya sektor pertanian berdasarkan analisis Location Quotien (LQ), serta klasifikasi sektor pertanian berdasarkan Tipologi Klassen.

\section{METODE PENELITIAN}

\section{Lokasi dan Data Penelitian}

Penelitian dilakukan di Kabupaten/Kota di Kawasan Solo Raya yaitu Kota Surakarta (Solo), Kabupaten Boyolali, Sukoharjo, Karanganyar, Wonogiri, Sragen, dan Klaten. Data yang digunakan adalah data sekunder berupa data Produk Domestik Regional Bruto (PDRB) Provinsi Jawa Tengah dan PDRB
Kabupaten/Kota di Solo Raya tahun 20102014 atas dasar harga konstan 2010.

\section{Metode Analisis Data}

1. Analisis Kontribusi Sektor Pertanian di Kawasan Solo Raya

Kontribusi sektor pertanian dihitung dengan membandingkan nilai PDRB sektor pertanian dengan total PDRB masingmasing Kabupaten/Kota di kawasan Solo Raya dikalikan $100 \%$.

2. Analisis Laju Pertumbuhan Sektor Pertanian di Kawasan Solo Raya

Laju pertumbuhan sektor pertanian merupakan perubahan PDRB sektor pertanian dari tahun- ke tahun dihitung dengan membandingkan nilai PDRB sektor pertanian tahun $t$ dengan dengan nilai PDRB sektor pertanian tahun sebelumnya dikalikan $100 \%$.

3. Analisis Location Quotient (LQ)

Analisis LQ digunakan untuk menentukan apakah sektor pertanian di kabupaten/kota di kawasan Solo Raya merupakan sektor basis atau non basis. Analisis LQ yang dihitung dengan rumus:

$$
\mathbf{L} \mathbf{Q}=\frac{v i / v t}{V i / V t}
$$

vi

: PDRB sektor pertanian masing-masing kabupaten/kota di Solo Raya

vt : PDRB total masingmasing kabupaten/kota di Solo Raya

Vi : PDRB sektor pertanian Jawa Tengah

Vt : PDRB total Jawa Tengah

Berdasarkan nilai LQ yang diperoleh, sektor pertanian diklasifikasikan menjadi:

a. LQ>1, sektor pertanian merupakan sektor basis artinya sekor pertanianmampu memenuhi kebutuhan wilayah sendiri dan dapat mengekspor ke wilayah lain.

b. $\mathrm{LQ}=1$, sektor pertanian merupakan sektor non basis artinya sekor pertanianhanya mampu memenuhi kebutuhan wilayah sendiri dan tidak dapat mengekspor ke wilayah lain.

c. $\mathrm{LQ}<1$, sektor pertanian merupakan sektor non basis artinya sektor pertanian belum memenuhi kebutuhan wilayah sendiri dan kekurangannya dipenuhi 
dengan mengimpor dari luar wilayah (Kuncoro, 2014).

4. Analisis Tipologi Klassen

Analisis Tipologi Klassen
mengklasifikasikan peranan sektor
pertanian berdasarkan dua indikator yaitu
kontribusi dan pertumbuhan
PDRB.Analisis Tipologi Klassen ini
dilakukan dengan:
a. Membandingkan besarnya kontribusi
PDRB sektor pertanian dengan
kontribusi PDRB masing-masing

kabupaten/kota di kawasan Solo Raya terhadap PDRB Provinsi Jawa Tengah.

b. Membandingkan laju pertumbuhan PDRB sektor pertanian dengan laju pertumbuhan PDRB masing-masing kabupaten/kota di kawasan Solo Raya

Berdasarkan perbandingan tersebut kemudian sektor pertanian diklasifikasikan menjadi sektor prima, potensial, berkembang dan terbelakang.Matrik Tipologi Klassen disajikan pada tabel 1.

Tabel 1. Matrik tipologi klassen

\begin{tabular}{|c|c|c|}
\hline $\begin{array}{l}\text { Kontribusi Sektor/Subsektor } \\
\text { i }\end{array}$ & $\begin{array}{l}\text { Kontribusi Besar } \\
\text { (Kontribusi sektor/subsektor } \\
\text { i } \geq \text { Kontribusi }{ }_{\text {PDRB }} \text { ) }\end{array}$ & $\begin{array}{l}\text { Kontribusi Kecil } \\
\text { (Kontribusi sektor/subsector } \\
{ }_{\mathrm{i}}<\text { Kontribusi PDRB }\end{array}$ \\
\hline $\begin{array}{l}\text { Laju } \\
\text { Pertumbuhan } \\
\text { Sektor/subsektor i }\end{array}$ & & \\
\hline $\begin{array}{l}\text { Tumbuh Cepat } \\
\left(\mathrm{r}_{\text {sektor/subsektor } \mathrm{i}} \geq \mathrm{r}_{\text {PDRB }}\right)\end{array}$ & $\begin{array}{l}\text { Sektor/subsector } \\
\text { Prima }\end{array}$ & $\begin{array}{l}\text { Sektor/subsektor } \\
\text { Berkembang }\end{array}$ \\
\hline $\begin{array}{l}\text { Tumbuh Lambat } \\
\left(\mathrm{r}_{\text {sektor/subsektor i }}<\mathrm{r}_{\mathrm{PDRB}}\right)\end{array}$ & $\begin{array}{l}\text { Sektor/subsector } \\
\text { Potensial }\end{array}$ & $\begin{array}{l}\text { Sektor/subsektor } \\
\text { Terbelakang }\end{array}$ \\
\hline
\end{tabular}
Sumber: Widodo 2006.

\section{HASIL DAN PEMBAHASAN}

\section{Kontribusi Sektor Pertanian dalam Perekonomian di Kawasan Solo Raya}

Kondisi dan struktur perekonomian suatu wilayah dapat dilihat melalui Produk Domestik Regional Bruto (PDRB). PDRB menggambarkan sektor-sektor perekonomian pembentuk ekonomi suatu wilayah dan peranan setiap sektor perekonomian terhadap ekonomi suatu daerah. Peranan sektor perekonomian terhadap ekonomi daerah dapat dilihat melalui sumbangan atau kontribusi masing-masing sektor ekonomi serta melalui perubahan kontribusinya dalam suatu kurun waktu tertentu (time series). PDRB yang disajikan secara series memberikan gambaran kinerja ekonomi makro dari waktu ke waktu sehingga arah perekonomian regional akan lebih jelas.

Kontribusi sektor pertanian dalam pembangunan ekonomi di kawasan Solo Raya disajikan pada tabel 2 .

Tabel 2. Kontribusi PDRB sektor pertanian terhadap total PDRB Kabupaten/Kota di kawasan Solo Raya tahun 2010-2014 (\%)

\begin{tabular}{lcccccc}
\hline Kabupaten/Kota & \multicolumn{7}{c}{ Tahun } \\
\cline { 2 - 7 } & 2010 & 2011 & 2012 & 2013 & 2014 & Rata-rata \\
\hline Sragen & 20,97 & 19,90 & 19,45 & 18,97 & 16,60 & 19,04 \\
Sukoharjo & 10,40 & 9,60 & 10,27 & 9,86 & 8,84 & 9,79 \\
Boyolali & 25,34 & 23,71 & 24,54 & 23,65 & 22,11 & 23,87 \\
Wonogiri & 36,92 & 35,88 & 35,42 & 34,15 & 32,69 & 35,01 \\
Surakarta & 0,50 & 0,52 & 0,51 & 0,54 & 0,52 & 0,52 \\
Karanganyar & - & 15,46 & 14,50 & 14,18 & 13,73 & 14,47 \\
Klaten & 13,43 & 12,31 & 12,94 & 12,73 & 11,91 & 12,68 \\
\hline
\end{tabular}

Sumber: Analisis data sekunder.

Tabel 2 menunjukkan bahwa dalam kurun waktu 2010-2014 sektor pertanian di Kabupaten/Kota kawasan Solo Raya memberikan kontribusi yang berfluktuatif namun cenderung menurun. Di antara kabupaten/kota di kawasan Solo Raya, 
Kabupaten Wonogiri memiliki kontribusi sektor pertanian terbesar disusul Kabupaten Boyolali, Sragen, Karanganyar, dan Klaten. Di kabupaten yang sektor pertanian memberikan kontribusi relatif besar menunjukkan bahwa di Kabupaten tersebut sektor pertanian memiliki peranan yang besar dalam perekonomian. Kota Surakarta memiliki kontribusi sektor pertanian terkecil di antara kabupaten/kota di kawasan Solo Raya yaitu rata-rata $0,52 \%$. Sektor pertanian di Kota Surakarta menempati urutan ke-14 di antara 17 sektor perekonomian pembentuk PDRB. Hal ini menunjukkan bahwa peranan sektor pertanian dalam perekonomian Kota Surakarta relatif kecil dibanding sektor perekonomian yang lain.

\section{Pertumbuhan sektor pertanian di kawasan Solo Raya}

Pertumbuhan ekonomi merupakan salah satu indikator penting dalam melakukan analisis tentang pembangunan ekonomi yang terjadi pada suatu negara (Yulianita, 2008). Pertumbuhan ekonomi merupakan perubahan tingkat ekonomi yang berlangsung dari tahun ke tahun (Sukirno, 1994). Pertumbuhan ekonomi dapat dilihat dari perkembangan nilai PDRB dari tahun ke tahun (Arsyad, 1997). Pertumbuhan ekonomi suatu daerah dibentuk oleh pertumbuhan PDRB setiap sektor pembentuk ekonomi daerah tersebut.

Pertumbuhan PDRB sektor pertanian dari tahun ke tahun menggambarkan perkembangan tingkat ekonomi sektor pertanian dan perkembangan peranan sektor pertanian dalam pembangunan ekonomi suatu daerah.Pertumbuhan PDRB sektor pertanian kabupaten/kota di kawasan Solo Raya disajikan pada tabel 3 .

Tabel 3. Pertumbuhan PDRB sektor pertanian di Kabupaten/Kota di kawasan Solo Raya tahun 2010$2014(\%)$

\begin{tabular}{lccccc}
\hline Kabupaten/Kota & \multicolumn{5}{c}{ Tahun } \\
\cline { 2 - 6 } & 2011 & 2012 & 2013 & 2014 & Rata-rata \\
\hline Sragen & 4,58 & 3,61 & 4,19 & $-7,60$ & 1,20 \\
Sukoharjo & $-2,18$ & 13,14 & 1,60 & $-5,61$ & 1,74 \\
Boyolali & 6,34 & 2,01 & 1,98 & $-1,78$ & 2,14 \\
Wonogiri & 0,67 & 4,56 & 1,04 & 0,77 & 1,76 \\
Surakarta & 15,17 & 8,20 & 16,88 & 7,01 & 11,81 \\
Karanganyar & - & 0,68 & 3,31 & 1,91 & 1,52 \\
Klaten & $-2,62$ & 11,10 & 2,56 & $-0,83$ & 3,05 \\
\hline
\end{tabular}

Sumber: Analisis data sekunder.

Tabel 3 menunjukkan bahwa pertumbuhan PDRB sektor pertanian di kawasan Solo Raya selama 2011-2014 berfluktiatif. Di Kabupaten Boyolali dan Klaten pertumbuhan PDRB sektor pertanian cenderung menurun. Pertumbuhan PDRB sektor pertanian tertinggi terdapat di Kota Surakarta yaitu rata-rata $11,81 \%$ dan terendah di Kabupaten Sragen dengan rata-rata $1,20 \%$. Rata-rata pertumbuhan PDRB sektor pertanian di Kota Surakarta tertinggi karena dalam kurun waktu 2011-2014 PDRB sektor pertanian selalu tumbuh positif dan relatif besar pertumbuhannya. Di Kabupaten Sragen rata-rata pertumbuhan PDRB sektor pertanian berfluktuatif dan pada tahun 2014 tumbuh negatif sebesar -7,60. Hal ini menyebabkan rata-ratanya rendah meskipun pada tahuntahun sebelumnya memiliki pertumbuhan yang relatif besar.

\section{Nilai LQ Sektor Pertanian di Kawasan Solo Raya}

Metode Location Quotient (LQ), merupakan perbandingan antara pangsa relatif pendapatan (tenaga kerja) sektor i pada tingkat wilayah terhadap pendapatan (tenaga kerja) total wilayah dengan pangsa relative pendapatan (tenaga kerja) sektor i pada tingkat nasional terhadap pendapatan (tenaga kerja) nasional (Budiharsono, 2011). Analisis location quotient (LQ) adalah cara untuk menentukan kemampuan suatu daerah di sektor produksi komoditas tertentu. Analisis LQ menyajikan perbandingan relatif antara kemampuan dari kegiatan produksi pertanian tertentu di daerah yang dilihat dari kemampuan sektor produksi yang sama di tingkat kabupaten (Zakaria, 2015). Hasil analisis LQ sektor pertanian masing-masing kabupaten/kota di kawasan Solo Raya disajikan pada tabel 4 . 
Tabel 4. Nilai LQ sektor pertanian Kabupaten/Kota di kawasan Solo Raya

\begin{tabular}{lcccccc}
\hline Kabupaten/Kota & \multicolumn{7}{c}{ Tahun } \\
\cline { 2 - 7 } & 2010 & 2011 & 2012 & 2013 & 2014 & Kriteria \\
\hline Sragen & 1,27 & 1,26 & 1,26 & 1,26 & 1,20 & Basis \\
Sukoharjo & 0,65 & 0,61 & 0.67 & 0,66 & 0,64 & Non Basis \\
Boyolali & 1,59 & 1,51 & 1,59 & 1,57 & 1,60 & Basis \\
Wonogiri & 2,31 & 2,28 & 2,30 & 2,29 & 2,36 & Basis \\
Surakarta & 0,03 & 0,04 & 0,03 & 0,03 & 0,03 & Non Basis \\
Karanganyar & - & 0,98 & 0,94 & 0,94 & 0,99 & Non Basis \\
Klaten & 0,84 & 0,78 & 0,84 & 0,85 & 0,87 & Non Basis \\
\hline
\end{tabular}

Sumber: Analisis data sekunder.

Berdasarkan tabel 4 dapat diketahui bahwa selama kurun waktu 2010-2014 nilai LQ sektor pertanian di kabupaten/kota kawasan Solo Raya berfluktuatif. Sektor pertanian merupakan sektor basis di Kabupaten Sragen, Boyolali, dan Wonogiri. Hal ini berarti bahwa peranan relatif sektor pertanian di kabupaten-kabupaten tersebut lebih besar daripada peranan relatif sektor pertanian dalam perekonomian di Provinsi Jawa Tengah. Hal ini juga berarti bahwa sektor pertanian mampu mencukupi kebutuhan wilayah tersebut dan mampu mengekspor kelebihan produkinya ke wilayah lain. Dengan demikian berarti bahwa sektor pertanian di kabupaten-kabupaten tersebut berperan penting dalam pembangunan ekonomi karena berkembangnya sektor basis akan memberikan pendapatan kepada daerah sebagai hasil dari ekspor dari kelebihan produksi yang dihasilkan.

Sedangkan di Kabupaten Sukoharjo, Karanganyar, Klaten dan Kota Surakarta sektor pertanian merupakan sektor non basis. Kondisi ini menunjukkan bahwa peranan sektor pertanian di wilayah tersebut lebih kecil dibandingkan dengan peranan sektor pertanian di Provinsi Jawa Tengah dan sektor pertanian belum mampu memenuhi kebutuhan kabupaten dan kota tersebut.

\section{Klasifikasi Sektor Pertanian di Kawasan Solo Raya berdasarkan Tipologi Klassen}

Tipologi Klassen digunakan untuk mengetahui gambaran tentang pola dan struktur pertumbuhan sektoral. Dalam Tipologi Klassen masing-masing sektor ekonomi dapat diklasifikasikan sebagai sektor prima, berkembang, potensial dan terbelakang. Analisis ini mendasarkan pengelompokan suatu sektor dengan melihat pertumbuhan dan kontribusi sektor tertentu terhadap total PDRB suatu daerah.

Hasil Analisis Tipologi Klassen sektor pertanian di kabupaten/kota kawasan Solo Raya disajikan pada tabel 5.

Tabel 5. Hasil analisis tipologi klassen sektor pertanian di kawasan Solo Raya

\begin{tabular}{lccccc}
\hline \multicolumn{1}{c}{$\begin{array}{c}\text { Kabupaten/ } \\
\text { Kota }\end{array}$} & $\begin{array}{c}\text { Kontribusi Sektor } \\
\text { Pertanian }\end{array}$ & $\begin{array}{c}\text { Kontribusi PDRB } \\
\text { Kabupaten/Kota }\end{array}$ & $\begin{array}{c}\text { Pertumbuhan } \\
\text { Sektor Pertanian }\end{array}$ & $\begin{array}{c}\text { Pertumbuhan PDRB } \\
\text { Kabupaten/Kota }\end{array}$ & Klasifikasi \\
\hline Sragen & 19,04 & 2,59 & 1,20 & 6,24 & Potensial \\
Sukoharjo & 9,79 & 2,65 & 1,74 & 5,71 & Potensial \\
Boyolali & 23,87 & 2,27 & 2,14 & 5,77 & Potensial \\
Wonogiri & 35,01 & 2,11 & 1,76 & 4,89 & Potensial \\
Surakarta & 0,52 & 3,82 & 11,81 & 10,53 & Berkembang \\
Karanganyar & 14,47 & 2,64 & 1,97 & 5,60 & Potensial \\
Klaten & 12,68 & 2,77 & 3,03 & 5,91 & Potensial \\
\hline
\end{tabular}

Sumber: Analisis data sekunder.

Tabel 5 menunjukkan bahwa sektor pertanian terkategori sebagai sektor potensial di 6 kabupaten yaitu Kabupaten Sragen, Sukoharjo, Boyolali, Wonogiri, Karanganyar dan Klaten. Sektor pertanian di kabupatenkabupaten tersebut memberikan kontribusi besar terhadap perekonomian namun pertumbuhannya lambat. Hal ini berarti bahwa kontribusi sektor pertanian terhadap PDRB masing-masing lebih besar daripada kontribusi PDRB kabupaten-kabupaten tersebut terhadap PDRB Jawa Tengah dan pertumbuhan sektor pertanian lebih lambat dibandingkan pertumbuhan PDRB masing-masing kabupaten. Besarnya kontribusi sektor pertanian di kabupaten tersebut disebabkan 
potensi wilayah yang menunjang sektor pertanian seperti luasnya lahan pertanian dan beragamnya aktivitas pertanian yang mencakup pertanian tanaman pangan, perkebunan, kehutanan, peternakan, maupun perikanan. Pertumbuhan sektor pertanian yang lambat dapat disebabkan produktivitas yang berkurang, adanya alih fungsi lahan, maupun rendahnya harga produk-produk pertanian terutama produk pertanian tanaman pangan.

Di Kota Surakarta sektor pertanian terkategori sebagai sektor berkembang. Hal ini menunjukkan bahwa kontribusi sektor pertanian terhadap PDRB Kota Surakarta lebih kecil daripada kontribusi PDRB Kota Surakarta terhadap PDRB Jawa Tengah namun pertumbuhan PDRB sektor pertanian di Kota Surakarta lebih cepat dibandingkan pertumbuhan PDRB Kota Surakarta. Kontribusi sektor pertanian kecil karena di Kota Surakarta lahan pertanian yang mencakup sawah dan tegalan hanya sebesar $4,7 \%$ dan sebagian besar wilayahnya merupakan wilayah pemukiman $(65,3 \%)$. Pertumbuhan PDRB sektor pertanian di Kota Surakarta yang tinggi antara lain disebabkan berkembangnya pertanian perkotaan yang banyak mengusahakan tanaman hortikultura terutama bunga dan buah. Produk hortikultura pada umumnya memiliki harga yang lebih tinggi dibandingkan produk tanaman pangan.

Berdasarkan hasil analisis tipologi Klassen , strategi peningkatan peranan sektor pertanian di Kabupaten Sragen, Sukoharjo, Boyolali, Wonogiri, Karanganyar dan Klaten dapat dilakukan dengan peningkatan laju pertumbuhan PDRB sektor pertanian. Sedangkan strategi peningkatan peranan sektor pertanian di Kota Surakarta dapat dilakukan dengan peningkatan kontribusi sektor pertanian terhadap PDRB.

\section{KESIMPULAN}

Kesimpulan dari penelitian ini yaitu (1) Selama tahun 2010-2014 kontribusi sektor pertanian terhadap PDRB Kabupaten/Kota di Kawasan Solo Raya cenderung menurun. Kontribusi sector pertanian terhadap PDRB tertinggi terdapat di Kabupaten Wonogiri yaitu rata-rata sebesar $35,01 \%$ dan terendah adalah di Kota Surakarta yaitu 0,52\%. (2) Hasil analisis LQ menunjukkan bahwa sektor pertanian menjadi sektor basis di Kabupaten Sragen, Wonogiri, dan Boyolali dan menjadi sektor non basis di Kabupaten Sukoharjo, Karanganyar, Klaten, dan Kota Surakarta. Dan (3) Hasil Analisis Tipologi Klassen menunjukkan sektor pertanian di 6 kabupaten yaitu Kabupaten Sragen, Sukoharjo, Boyolali, Wonogiri, Karanganyar, dan Klaten, terkategori sebagai sektor potensial sedangkan di Kota Surakarta terkategori sebagai sektor berkembang.

\section{DAFTAR PUSTAKA}

Arsyad, L. 1997. Ekonomi Pembangunan. Bagian Penerbitan STIE YKPN, Yogyakarta.

2009. Ekonomi Pembangunan Edisi ke-2. Bagian Penerbitan Sekolah Tinggi Ilmu Ekonomi. YKPN. Yogyakarta.

Budiharsono, S. 2001. Teknik Analisis Pembangunan Wilayah Pesisir dan Lautan. PT Pradnya Paramita. Jakarta.

Cahyono, S. A. dan W. W. Wijaya.2014. Inentifikasi sektor ekonomi unggulan dan ketimpangan pendapatan antar Kabupaten di Sub DAS Bengawan Solo Hulu. Jurnal Penelitian Sosial dan Ekonomi Kehutanan. Vol. 11 No. 1, Maret 2014, Hal: 32-43.

Darsono, S. Marwanti, dan U. Barokah. 2011. Dinamika peranan sektor pertanian dalam penyerapan tenaga kerja dan strategi peningkatan produktivitas tenaga kerja sektor pertanian di kawasan Subosuka Wonosraten. Jurnal Rural and Development edisi Agustus 2011.

Grup Bank Dunia. 2008. Laporan Pembangunan Dunia 2008: Pertanian untuk Pembangunan. Salemba Empat. Jakarta.

Kementerian Pertanian RI. 2015. Rencana Strategis Kementerian Pertanian 20152019.

Kuncoro, M. 2004. Otonomi dan Pembangunan Daerah : Reformasi, Perencanaan, Strategi dan Peluang. Erlangga. Jakarta.

Kuncoro, M., 2014. Otonomi Daerah: Menuju Era Baru Pembangunan Daerah (3rd ed.). Penerbit Erlangga. Jakarta. 
Sukirno, S. 1994. Pengantar Makro Ekonomi. (Edisi kedua). PT Grafindo, Jakarta.

Todaro, M.P. 1999. Pembangunan Ekonomi di Dunia Ketiga Edisi Keenam.Erlangga. Jakarta.

Widodo, T. 2006. Perencanaan Pembangunan: Aplikasi Komputer (era Otonomi Daerah). UPP STIM YKPN. Yogyakarta
Yulianita, A. 2008. Analisis Sektor Unggulan dan Pengeluaran Pemerintah di Kabupaten Ogan Komering Ilir. Journal of economic and Development. Hal 7085 .

Zakaria, J., 2015. A Study of Plantation Sector in Indonesia. International Journal of Business and Management Invention Vol. 4(2), pp. Hal 14-18. 